\title{
CUERPO EXTRAÑO PUNZANTE LOCALIZADO EN APÉNDICE CECAL, DE DOS MESES DE EVOLUCIÓN. EXTRACCIÓN POR COLONOSCOPIA - INFORME DE CASO.
}

Yépez Andrés Fernando ${ }^{1}$, Cadena Iván Rolando ${ }^{2 *}$, Correa Neicy Graciela ${ }^{3}$.

DOI: $10.48018 /$ rmv.v32.i1.S5

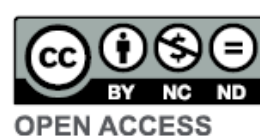

Este artículo está bajo una licencia de Creative Commons de tipo Reconocimieno - No comercial - Sin obras Herivadas 4.0 International.

1. Hospital del día del Instituto Ecuatoriano de Seguridad Social "IESS" Sangolquí. Médico del Servicio de Gastroenterología. Quito, Ecuador.

2. Hospital del día del Instituto Ecuatoriano de Seguridad Social "IESS" Sangolquí. Médico de Áreas Quirúrgicas. Quito, Ecuador.

3. Humana SA. Médico Auditor. Quito, Ecuador.

ORCID ID:

Yépez Andrés Fernando

orcid.org/0000-0001-5722-7490

Cadena Iván Rolando

orcid.org/0000-0002-8860-7434

Correa Neicy Graciela

orcid.org/0000-0001-7734-3085

* Corresponding author:

Cadena Iván Rolando

E-mail: ivan10dc@gmail.com

Article history: Manuscript presented at the 1 Clinical Case Contest - Hospital Vozandes Quito, February 27, 2021

CARE 2017 Check List statement: The authors have real the CARE 2017 Check List and the manuscript was prepared and revised according to the CARE 2017 Checklist.

Conflict of interest: All authors declared that there are no conflicts of interest.

Financial disclosure: The authors have no financial relationships relevant to this article to disclose.

Forma de citar este artículo: Yépez AF, Cadena IR, Correa NG. CUERPO EXTRAÑO PUNZANTE LOCALIZADO EN APÉNDICE CECAL, DE DOS MESES DE EVOLUCIÓN. EXTRACCIÓN POR COLONOSCOPIA INFORME DE CASO. Rev Med Vozandes. 2021; 32 (1 Suppl 1): S9-S10

\section{Resumen}

Introducción: La ingestión de cuerpos extraños implica un riesgo del 35\% de posibles complicaciones, las cuales están asociadas al tipo (romo o punzante) y al tamaño de los mismos. Si bien en la mayoría de ellos, se espera que pasen a lo largo del tracto gastrointestinal sin dificultad o complicaciones, el manejo dependerá de las características del objeto deglutido, tiempo de evolución y sintomatología del paciente.

Descripción del Caso: Presentamos el caso clínico de una paciente femenina de 58 años de edad con antecedente quirúrgico de Bypass gástrico reciente, quien accidentalmente ingiere una pieza metálica del equipo odontológico hace dos meses atrás, manteniéndose asintomática hasta acudir a nuestra consulta. En los controles radiográficos para confirmación, localización y evolución, se evidenció la presencia de un objeto punzante de $2 \mathrm{~cm}$, localizado aparentemente en apéndice cecal, que no progresa a distal. Para el manejo se planteó manejo expectante inicial que se completó con colonoscopia terapéutica para su extracción, la técnica recomienda que el objeto punzante debe ser agarrado por el extremo puntiagudo, distalmente a la pared, lo que reduce el riesgo de perforación relacionada al procedimiento o daño de la mucosa durante la extracción, se finaliza el caso con resolución exitosa y sin complicaciones.

Conclusión: El manejo terapéutico menos invasivo como la colonoscopia, debe ser considerado como de primera línea en este tipo de casos, cuando no existen signos o hallazgos radiológicos de perforación o inestabilidad clínica, debido a su baja incidencia de complicaciones y una alta tasa de éxito. 


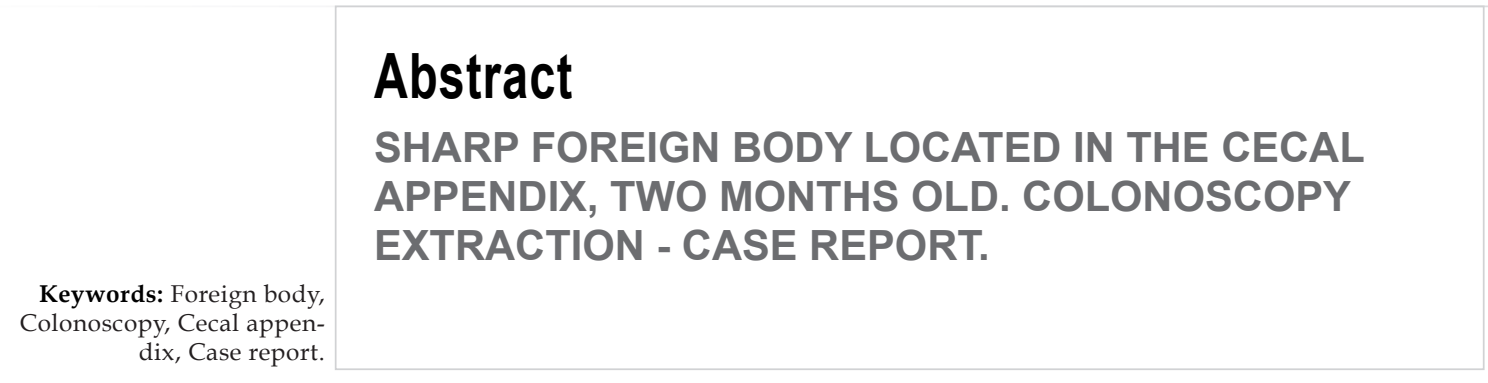

Introduction: Ingestion of foreign bodies implies a $35 \%$ risk of possible complications, which are associated with their type (blunt or sharp) and their size. Although in most of them, it is expected that they pass along the gastrointestinal tract without difficulty or complications, the management will depend on the characteristics of the swallowed object, time of evolution and symptoms of the patient.

Case description: We present the clinical case of a 58-year-old female patient with a recent gastric bypass surgical history, who accidentally ingested a piece of dental equipment two months earlier during a dental procedure, remaining asymptomatic until she came to our office. In radiographic controls for confirmation, location and evolution, the presence of a $2 \mathrm{~cm}$ sharp object was evidenced, apparently located in the cecal appendix, which does not progress distally. For the management, initial expectant management was proposed, which was completed with therapeutic colonoscopy for its extraction, the technique recommends that the sharp object should be grasped by the pointed end, distal to the wall, which reduces the risk of perforation related to the procedure or damage of the mucosa during extraction, the case is completed with successful resolution and without complications.

Conclusion: Less invasive therapeutic management such as colonoscopy should be considered first line in this type of case, when there are no signs or radiological findings of perforation or clinical instability, due to its low incidence of complications and a high success rate. 